\title{
PENGEMBANGAN MULTIMEDIA INTERAKTIF BERBASIS MOBILE LEARNING POKOK BAHASAN PERKEMBANGAN TEORI ATOM MATA PELAJARAN KIMIA KELAS X SMA PANJURA MALANG
}

\author{
Merra Rorita ${ }^{1}$, Saida Ulfa ${ }^{2}$, Agus Wedi ${ }^{3}$ \\ Universitas Negeri Malang \\ E-mail: roritamerra@gmail.com
}

\begin{abstract}
ABSTRAK
Kemajuan teknologi pada era sekarang, berpengaruh pula pada perkembangan media pembelajaran yaitu multimedia interaktif dengan pemanfaatan yang menggunakan smartphone. Hal ini memungkinkan untuk digunakan dimanapun dan kapanpun.Tujuan penelitian ini yaitu menghasilkan multimedia interaktif berbasis mobile learning pokok bahasan perkembangan teori atom yang tervalidasi dan efektif dalam kegiatan pembelajaran Kimia kelas X SMA. Pengembangan ini telah melalui tahap analisis, desain, pengembangan, implementasi dan evaluasi sesuai dengan model pengembangan Lee dan Owens (2004). Validasi produk dilakukan terhadap ahli media dan ahli materi. Sasaran uji coba media ini adalah siswa kelas X IPA SMA Panjura Malang. Pengembangan ini menghasilkan kriteria valid dengan perolehan total persentase ahli media 96,25\%, ahli materi 87,5\%, uji coba perseorangan 86,25\%, uji coba kelompok kecil 86,25\% dan uji coba lapangan 89,48\%. Selain itu, Multimedia interaktif berbasis mobile learning ini dikategorikan efektif untuk digunakan pada kegiatan pembelajaran berdasarkan pada ketuntasan hasil belajar siswa mencapai 100\%.
\end{abstract}

Kata kunci: Multimedia Interaktif, Mobile Learning, Perkembangan Teori Atom.

\section{PENDAHULUAN}

Paradigma pendidikan berkembang menuju pembelajaran modern dengan memanfaatkan teknologi. Teknologi di bidang pendidikan merupakan alat atau cara yang dimanfaatkan untuk memudahkan kegiatan pembelajaran. Teknologi yang berperan penting untuk pembelajaran di sekolah bisa dilihat dari media yang digunakan siswa sebagai alat bantu pembelajaran. Alat bantu dalam kegiatan belajar ini merupakan media untuk mempermudah guru dalam menyampaikan materi pelajaran. Bentuk media pembelajaran ada berbagai macam yaitu bahan ajar cetak, gambar, audio, video, animasi dan lain-lain. Untuk lebih memudahkan pebelajar dalam memahami materidapat menggabungkan beberapa unsur media pembelajaran. Media pembelajaran seperti ini disebut multimedia. Menurut Purnama (2013), multimedia merupakan kombinasi teks, yang dimanipulasi secara digital, seni grafis, animasi dan elemen video. Menurut Praherdiono\& Adi (2008), kelebihan multimedia adalah menarik indera dan menarik minat karena menggabungkan antara pandangan, suara dan gerakan.

Kimia merupakan ilmu sains yang mempelajari tentang susunan dan perubahan sifat pada objek yang membutuhkan ruang. Materi dasar yang dipelajari dalam kimia adalah atom. Pokok pembahasan atom seringkali disepelekan untuk dipelajari lebih dalam. Dampaknya, untuk materi pembelajaran selanjutnya, peserta didik kesulitan mengimajinasikan bagaimana kondisi dan sifat atom yang sebenarnya.

Berdasarkan wawancara non formal yang dilakukan di SMAN Panjura Malang, menunjukkan bahwa sebagian peserta didik kelas $\mathrm{X}$ jurusan IPA tidak paham mengenai atom. Peserta didik kesulitan menvisualisasikan dan memahami perkembangan teori atom yang disampaikan dari bahan ajar buku yang digunakan di sekolah. Menurut siswa, penjelasan di buku tidak membantu dalam penguasaan pokok bahasan perkembangan teori atom. Selama ini, hanya bahan ajar bukuyang digunakan guru menyampaikan materi. Pembelajaran yang hanya 
menggunakan buku terkesan kurang menarik. Hal ini mempengaruhi pemahaman siswa mengenai atom. Menurut siswa, penjelasan di buku kurang mampu menvisualisasikan model atom sehingga mereka mengakui bahwa tidak suka belajar menggunakan buku karena kesulitan memahami penjelasannya. Siswa mengharapkan ada media pembelajaran yang bisa mengatasi kesulitan belajar siswa mengenai atom dan memotivasi belajar mereka.

Berdasarkan pemaparan diatas, peran media pembelajaran sangat dibutuhkan dalam kegiatan belajar yang mampu memberikan pemahaman siswa terhadap atom. Dengan kemajuan teknologi era sekarang, berpengaruh pula pada perkembangan media pembelajaran yaitu multimedia interaktif. Arti kata interaktif sendiri menurut KBBI yakni bersifat saling aktif. Multimedia interaktif adalah media pembelajaran yang pengoperasiannya ada pada pengguna. Menurut Purnama (2013), multimedia interaktif adalah gabungan dari teks digital, audio gambar, grafik, animasi dan video yang dikontrol oleh pengguna.

Multimedia pada pengembangan ini adalah multimedia interaktif berbasis mobile learning, dimana dalam penggunaannya memanfaatkan smartphone Android. Diketahui bahwa mayoritas siswa di SMA Panjura Malang memiliki dan dapat mengoperasikan smartphone yang beroperasi sistem Android. Dari wawancara kepada pihak sekolah, bahwasanya siswa tidak dilarang membawa telepon seluler. Dalam pembelajaran secara individu,multimedia interaktif berbasis mobile learning sangat efektif digunakan dan cocok dengan keadaan siswa saat ini. Kelebihannya, siswa dapat mengoperasikan sendiri media tersebut kapan saja dan dimana saja. Siswa akan lebih maksimal memanfaatkan smartphone yang sebelumnya jarang digunakan untuk proses pembelajaran. Darmawan (2013) menjelaskan mobile learning merupakan alternatif layanan pembelajaran harus dilaksanakan dimanapun dan kapanpun. Dengan memanfaatkan smartphone ini, pembelajaran akan memudahkan akses siswa.

Hal inilah yang melatarbelakangi pengembangan multimedia interaktif berbasis mobile learning yakni permasalahan dalam penggunaan sumber belajar di SMA Panjura Malang. Selain efektif untuk penggunaan pembelajaran secara individu, multimedia interaktif mobile learning ini juga dapat digunakan oleg guru dalam pembelajaran di kelas. Hal tersebut sejalan dengan konsep pembelajaran yang dilakukan secara kelompok di dalam kelas. Jadi, siswa bisa mengakses secara individu ketika mengikuti pembelajaran dikelas. Multimedia interaktif dalam pengembangan ini juga dijadikan media pelengkap dan latihan bagi siswa dalam mengerjakan soal mengenai materi perkembangan atom.Aplikasi yang dikembangkan ini nantinya berfungsi sebagai pelengkap (komplemen) dalam kegiatan pembelajaran. Menurut Darmawan (2012), multimedia interaktif sebagai pelengkap(komplemen)dengan situasi guru dapat menggunakan buku berdampingan dengan multimedia berbasis mobile learning untuk penguasaaan wawasan terkait materi yang disajikan dalam media. Sehingga media dijadikan sebagai program pengayaan materi bagi siswa dalam mengatasi kesulitan pemahaman materi di buku.

Berdasarkan pemaparan di atas yang melatarbelakangi penelitian pengembangan ini makapeneliti melakukan penulisan skripsi dengan judul "Pengembangan Multimedia Interaktif Berbasis Mobile Learning Pokok Bahasan Perkembangan Teori Atom Kimia Kelas X SMA Panjura Malang.

Multimedia interaktif dalam kegiatan pembelajaran tidak hanya dimanfaatkan oleh guru sebagai bahan ajar dikelas. Multimedia interaktif juga dapat dijadikan sebagai bahan pembelajaran individu oleh siswa yang dapat diakses diluar kegiatan 
belajar dikelas. siswa memiliki keberagaman karakeristik belajar. Menurut teori Quantum Laerning (Rusman, 2012), siswa dengan modalitas belajar yang berbeda, dibedakan menjadi 3 tipe yaitu visual, auditif dan kinestetik. Keberagaman modalitas belajar tiap siswa dapat diatasi menggunakan multimedia interaktif.

Sementara itu, mobile learning merupakan pembelajaran dengan memanfaatkan perangkat mobile seperti mobile phone, laptop dan peralatan teknologi informasi lain untuk pembelajaran (Sutopo, 2012). Alternatif untuk memanfaatkan teknologi sebagai inovasi pembelajaran adalah menggunakan multimedia interaktif berbasis mobile learning. Sejalan dengan pendapat tersebut, West dalam (Irawan, 2014) mengemukakan bahwa mobile technology merupakan hal potensial yang dapat meningkatkan kualitas pembelajaran.

Beberapa pendapat para ahli di atas, disimpulkan bahwa mobile learning adalah kegiatan pembelajaran yang memanfaatkan perangkat mobile untuk mengaksesnya. Multimedia interaktif berbasis mobile learning yang dikembangkan termasuk dalam pembelajaran yang memanfaatkan mobile sebagai perangkat aksesnya dengan menggunakan smartphone Android siswa.

Berdasarkan pemaparan di atas, adapun tujuan yang ingin dicapai dalam penelitian pengembangan multimedia interaktif adalah mengembangkan media pembelajaran berupa multimedia interaktif berbasis mobile learning yang valid dan efektif untuk digunakan dalam proses pembelajaran serta sesuai dengan kebutuhan pebelajar.

\section{METODE PENELITIAN}

Penelitian pengembangan ini menggunakan model penelitian dan pengembangan yang diadaptasi dari model pengembangan oleh Lee \& Owens (2004). Model ini digunakan karena sesuai untuk diterapkan pada penelitian pengembangan multimedia interaktif berbasis mobile learning dengan tahap-tahap yang sesuai. Tahapan-tahapan tersebut meliputi, (1) tahap analisis, (2) tahap desain, (3) tahap pengembangan, (4) tahap implementasi dan (5) tahap evaluasi.

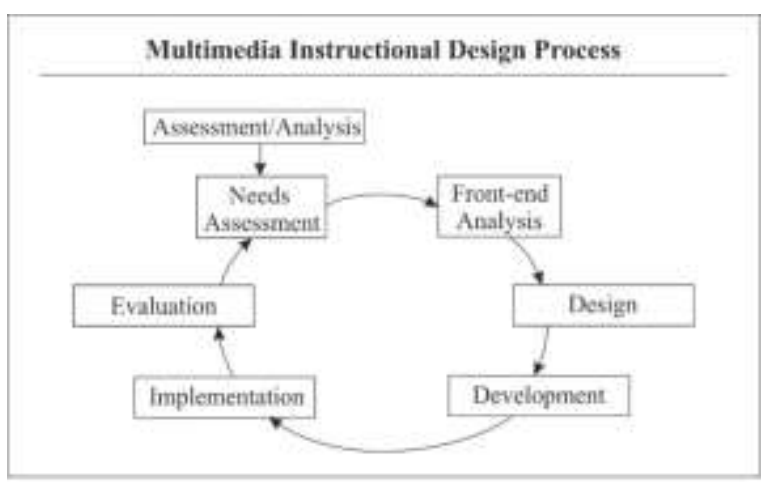

Bagam Model Penelitian dan Pengembangan Lee \&Owens (2004)

Tahap analisis merupakan awal penelitiandigunakan untuk mencari masalah dan solusi yang dibutuhkan oleh siswa kelas X SMA Panjura Malang. Terdapat dua langkah kegiatan pada tahap analisis. Langkah pertama yaitu need assesment dan langkah kedua yaitu frontend analysis.Need assessment yaitu cara sistematis menentukan permasalahan antara situasi yang sebenarnya dengan situasi yang diinginkan. Analisis kebutuhan dilakukan melalui wawancara dan observasi oleh peneliti terhadap guru dan siswa SMA Panjura Malang dapat diketahui bahwa tidak ada penggunaan variasi media dalam pembelajaran. Pembelajaran berlangsung hanya menggunakan bahan ajar buku. Hal ini mengakibatkan siswa kesulitan dalam pemahaman pokok bahasan "Perkembangan Teori Atom" dan sulit memvisualisasikan keadaan atom hanya dengan penjelasan teks dan gambar.FrontEnd Analysis merupakan tahap menentukan solusi yang diperlukan untuk mangatasi masalah dengan menganalisis kebutuhan melalui data dan informasi yang sudah dikumpulkan (Lee \& Owens, 2004). Berikut adalah jenis analisis awal dan akhir yaitu, (1) analisis audiens, (2) analisis teknologi, (3) analisis situasi, (4) analisis 
tugas, (5) analisis kejadian kritis, (6) analisis isu, (7) analisis tujuan, (8) analisis media, (9) analisis data, (10) analisis biaya.

Tahap desain merupakan tahap perencanaan mengenai media yang dikembangkan. Menurut Lee \&Owens (2004) terdapat beberapa langkah yang dilakukan dalam tahap ini meliputi: 1) menentukan jadwal pengembangan, 2) menentukan tim proyek, 3) menentukan spesifikasi media, 4) menentukan struktur konten, 5) kontrol konfigurasi terhadap rencana proyek.

Tahap pengembangan yaitu membangun multimedia dengan memasukkan materi yang sudah disiapkan. Pengembang menggunakan Appypie untuk membangun program multimedia interaktif dengan didukung CorelDraw X7 sebagai pengolah gambar. Adapun langkahlangkah yang dilakukan dalam tahap pengembangan antara lain: 1) membuat kerangka, 2) mngembangkan elemenelemen media, 3) melakukan review dan merevisi produk.

Tahap implementasi dilakukan setelah melewati tahap-tahap diatas. Pada tahap ini multimedia interaktif sudah dinyatakan siap digunakan dan direvisi kembali apabila pada tahap selanjutnya masih ditemukan kekurangan pada produk yang sudah dikembangkan.

Tahap evaluasi ditujukan untuk pencapaian produk yang dikembangkan sesuai tujuan yang ditetapkan. Beberapa langkah pada tahap evaluasi antara lain: 1) menentukan tujuan dari evaluasi, 2) menyusun dan merencanakan strategi evaluasi, 3) mengukur validitas, 4) pengembangan instrumen,

Mengumpulkan dan Analisis Data.

Penelitian ini menggunakan instrumen yang berupa angket untuk menguji validitas media yang dilakukan. Sedangkan untuk mengukur efektivitas produk menggunakan tes hasil belajar berupa soal. Proses pengumpulan data dilakukan oleh pengembang dengan langsung melakukan penelitian ke lapangan.
Dalam mengolah data keseluruhan, menggunakan rumus dari Arikunto (2010) sebagai berikut:

$\mathrm{P}=\sum_{\sum \mathrm{X} \mathrm{X}} \times 100 \%$

Keterangan rumus:

$\mathrm{P} \quad=$ Persentase

$\sum \mathrm{X}=$ Skor responden dalam satu item

$\sum \mathrm{Xi}=$ Jumlah skor ideal dalam satu item

$100 \%=$ Konstanta

Hasil dari pengelolaan data diatas, akan dilihat tingkat validitasnya dengan kriteria sebagai berikut.

\begin{tabular}{ll}
\hline Persentase & Ekuivalen \\
\hline $80 \%-100 \%$ & Valid dan layak \\
$60 \%-79 \%$ & $\begin{array}{l}\text { Cukup valid dan cukup } \\
\text { layak }\end{array}$ \\
$50 \%-59 \%$ & $\begin{array}{l}\text { Kurang valid dan kurang } \\
\text { layak }\end{array}$ \\
$0 \%-49 \%$ & $\begin{array}{l}\text { Tidak valid dan tidak } \\
\text { layak }\end{array}$
\end{tabular}

Pengolahan data tes hasil belajar dalam penelitian ini diperoleh dengan menghitung hasil tes subjek uji coba. Uji coba dilakukan terhadap 18 siswa di SMA Panjura Malang. Untuk menghitung tes hasil belajar adalah dilakukan dengan cara membandingkan dengan acuan Kriteria Ketuntasan Minimun (KKM) di SMA Panjura Malang. KKM mata pelajaran Kimia kelas X SMA Panjura Malang adalah 70. Berikut cara pengolahan datanya (Arikunto, 2010): 
Dalam menentukan keefektifan hasil belajar setelah menggunakan media dapat dilihat dari kriteria keberhasilan sebagai berikut:

\begin{tabular}{ll}
\hline Rentangan & Kualifikasi \\
\hline $80-100$ & Efektif \\
$60-79$ & Cukup Efektif \\
$40-59$ & Kurang Efektif \\
$<40$ & Tidak Efektif \\
\hline
\end{tabular}

\section{HASIL DAN PEMBAHASAN}

Validasi media dilakukan pada ahli media dan ahli materi. Untuk uji coba dilakukan tiga kali yaitu uji coba perseorangan, uji coba kelompok kecil dan uji coba lapangan. Validasi ini dilakukan untuk mengukur tingkat validitas mobile learning yang sudah dikembangkan. Selanjutnya, setelah mengukur validitas media, dalam penelitian ini juga dilakukan tes hasil belajar setelah menggunakan media pada proses pembelajaran. Untuk mengukur efektivitas mobile learning pada kegiatan pembelajaran, dilakukan tes hasil belajar.

Data validasi ahli media didapat dari 1 ahli media pembelajaran. Data validasi ahli materi didapat dari 1 guru Kimia. Data uji coba perseorangan diperoleh dari 2 siswa, data uji coba kelompok kecil diperoleh dari 4 siswa dan data uji coba lapangan diperoleh dari 12 siswa. Variabel yang menjadi pengamatan tentang mobile learning disajikan pada tabel berikut:

Perolehan darivalidasi ahli media, terdapat 17 pertanyaan termasuk dalam kategori valid dan terdapat 3 pertanyaan dapat dikatakan cukup valid. Secara keseluruhan diperoleh hasil 96,25\% maka berdasarkan kriteria yang ditentukan dapat dijelaskan bahwa mobile learning pokok bahasan perkembangan teori atom kelas $\mathrm{X}$ SMA memiliki kriteria valid dan layak digunakan dalam pembelajaran.
Hasil validasi ahli materi, terdapat 10 pertanyaan termasuk dalam kategori valid dan terdapat 10 pertanyaan termasuk dalam kategori cukup valid. Secara keseluruhan diperoleh hasil 87,5\% maka berdasarkan kriteria yang ditentukan dapat dijelaskan bahwa mobile learning pokok bahasan perkembangan teori atom kelas X SMA memiliki kriteria valid dan layak untuk proses pembelajaran.

Data hasil uji coba perseorangan secara keseluruhan diperoleh hasil 86,25\% maka berdasarkan kriteria yang ditentukan dapat dijelaskan bahwa mobile learning pokok bahasan perkembangan teori atom kelas X SMA memenuhi kriteria valid dan layak digunakan dalam pembelajaran.

Data hasil uji coba kelompok kecil secara keseluruhan diperoleh hasil 86,25\% maka berdasarkan kriteria yang ditentukan dapat dijelaskan bahwa mobile learning pokok bahasan perkembangan teori atom kelas X SMA memenuhi kriteria valid dan layak digunakan dalam pembelajaran.

Hasil uji coba lapangan secara keseluruhan diperoleh hasil 89,48\% maka berdasarkan kriteria yang ditentukan dapat dijelaskan bahwa mobile learning pokok bahasan perkembangan teori atom kelas $\mathrm{X}$ SMA memiliki kriteria valid dan layak digunakan dalam pembelajaran.

Padahasil tes belajar setelah menggunakan mobile learning pada pembelajaran Kimia secara keseluruhan diperoleh hasil persentase 100\% maka berdasarkan kriteria yang ditentukan termasuk efektif dengan persentase $80 \%$ $100 \%$ dapat disimpulkan bahwa mobile learning pokok bahasan perkembangan teori atom kelas X SMA termasuk dalam kategori efektif.

\section{KESIMPULAN}

Multimedia sangat dibutuhkan untuk mempermudah siswa dalam memahami materi mengenai perkembangan teori atom pada mata pelajaran Kimia kelas X.Selaras dengan tujuan pengembangan dalam penelitian ini, multimedia interaktif memenuhi kriteria valid. Artinya, 
multimedia interaktif ini sudah layak digunakan pada kegiatan pembelajaran.Selain itu, multimedia interaktif juga efektif dalam meningkatkan pembelajaran. Multimedia interaktif dikembangkan berdasarkan tujuan pembelajaran yang ingin dicapai. Mobile learning difungsikan sebagai komplemen (pelengkap) dalam kegiatan pembelajaran. Sebagaimana fungsi komplemen dalam pembelajaran, media ini dijadikan alat atau cara untuk meningkatkan pengetahuan siswa dan mengatasi kesulitan siswa dalam memahami materi di buku.

Media ini dapat dimanfaatkan dalam kegiatan pembelajaran di kelas maupun secara mandiri. Kelebihan dari mobile learning ini dibandingkan dengan pengembangan media sebelumnya adalah tidak membutuhkan penyimpanan data yang besar pada smartphone. Hal ini berpengaruh pada kelancaran dalam pengoperasiannya. Dalam mengakses media ini membutuhkan jaringan internet. Selain itu, mobile learning ini dapat diperbarui sesuai dengan kebutuhan pembelajaran. Kuis pada media juga dapat diperbarui.

Saran dalam pemanfaatan media ini agar pembelajaran dikelas berjalan lancar yaitu guru berperan sebagai pendamping yang memandu siswa dalam menggunakan media dan memberikan bantuan kepada siswa yang mengalami kesulitan. Serta ketika kegiatan pembelajaran selesai, guru dapat mengevaluasi dengan melakukan tanya jawab terhadap siswa. Selain itu, bagi pengembang produk selanjutnya, ada saran dalam pengembangan produk lebih lanjut yaitu menghilangkan iklan ketika aplikasi berjalan agar tidak mengganggu pengguna dalam kegiatan pembelajaran.

\section{DAFTAR PUSTAKA}

Arikunto, S., Abdul Jabar C.S. 2014. Evaluasi Program Pendidikan. Jakarta: PT Rineka Cipta.

Darmawan, Deni, 2012. Inovasi Pendidikan. Bandung: PT Remaja Rosdakarya.

Darmawan, Deni. 2013. Teknologi Pembelajaran. Bandung: PT Remaja Rosdakarya.

Irawan, W.I. 2014. Peranan Pembelajaran Mobile Learning. Yogyakarta: Pustaka Belajar.

KBBI. Tanpa Tahun. Interaktif, (Online), (http://www.kbbi.web.id/internet), diakses 7 Februari 2018

Lee, W.W \& Owens, D.L. 2004. Multimedia Based Instructional Design. San Francisco: Pfeiffer.

Purnama, Bambang Eka, 2013. Konsep Dasar Multimedia. Yogyakarta: Graha Ilmu.

Praherdiono, Henry \& Adi, Eka Pramono. 2008. Panduan Praktikum Multimedia. Malang: Fakultas Ilmu Pendidikan Universitas Negeri Malang.

Rusman. 2012. Model-Model Pembelajaran. Depok: PT Rajagrafindo Persada.

Sutopo, Ariesto Hadi. 2012. Teknologi Informasi dan Komunikasi dalam Pendidikan. Yogyakarta: Graha Ilmu 